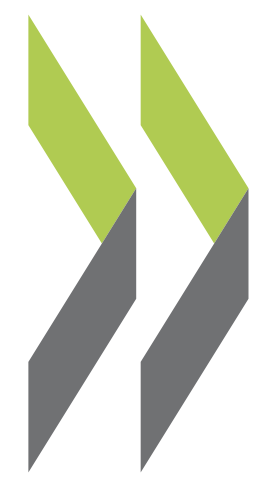

OECD Working Papers on Insurance and Private Pensions No. 30

\title{
Pensions in Africa
}

\section{Fiona Stewart,}

\section{Juan Yermo}




\section{\ęC}

PENSIONS IN AFRICA

Fiona Stewart and Juan Yermo

January 2009

OECD WORKING PAPER ON INSURANCE AND PRIVATE PENSIONS

No. 30

Financial Affairs Division, Directorate for Financial and Enterprise Affairs

Organisation for Economic Co-operation and Development

2 Rue André Pascal, Paris 75116, France

www.oecd.org/daf/fin/wp 


\begin{abstract}
RÉSUMÉ

\section{Pensions in Africa}

This paper discusses why the development of pension systems is important for the African region. It also looks at the current pension arrangements in selected African countries.

The paper was designed as an overview/background document to provide context and assist discussion at the OECD/IOPS Global Forum on Private Pensions, which was held in Mombasa, Kenya on the $30^{\text {th }} / 31^{\text {st }}$ October, 2008. The OECD and IOPS acknowledge the leadership of other organisations in terms of development and African specific issues - notably the World Bank, International Labor Organisation (ILO) and IMF.
\end{abstract}

JEL codes: G15 G18 G23 G28 J26

Keywords: Africa, demographics, funding, pensions, poverty alleviation, social policy

$* * * * *$

\title{
Les retraites en Afrique
}

Le présent document examine les raisons pour lesquelles le développement des systèmes de retraite est important pour la région de l'Afrique. Il décrit également les dispositifs de retraite en vigueur dans un certain nombre de pays africains.

Il s'agit d'un document de synthèse/d'information destiné à situer et à faciliter les débats du Forum mondial OCDE/OICP sur les pensions privées qui s'est tenu à Mombasa (Kenya) les 30 et 31 octobre 2008. L'OCDE et l'OICP tiennent à souligner le rôle prépondérant d'autres organisations dans le domaine du développement et en ce qui concerne les questions liées à l'Afrique - notamment la Banque mondiale, l'Organisation internationale du travail (OIT) et le FMI.

Classification JEL : G15 G18 G23 G28 J26

Mots clés : Afrique, démographie, financement, retraites, réduction de la pauvreté, politique sociale

\section{Copyright OECD, 2009}

Applications for permission to reproduce or translate all, or part of, this material should be made to: Head of Publications Service, OECD, 2 rue André-Pascal, 75775 Paris Cédex 16, France. 


\title{
PENSIONS IN AFRICA
}

\author{
by Fiona Stewart and Juan Yermo ${ }^{1}$
}

\section{Why Pensions in Africa?}

At first sight, pensions may not appear to be the most pressing issue for the African region. Whilst social security is to some extent discussed, private (or rather funded) pensions are rarely debated. One may well ask why address this topic at all, given more critical policy priorities for the region such as education, health, poverty alleviation or agricultural development, and given the lack of demographic pressure in general?

The urgent issue for pension reform in Africa is not only the need to introduce social protection systems - to help alleviate demographic pressures, poverty amongst the elderly and provide support for households headed by grandparents following the HIV AIDS pandemic and regional conflicts. In addition there is a vital need for reform of existing pension systems in the region, the cost of which is often crowding out spending on other key areas (such as health and education). Coverage of these systems is low (under 10 or often under 5 percent of the population) and usually only for civil servants or a minority of relatively highly paid workers in formal sector employment, making for highly regressive systems, with cross-subsidies required from indirect taxes (usually VAT) as pension payments from these systems frequently exceed contributions. The need for efficient pension arrangements in the region is undoubted though the challenges for introducing them remain great (notably the large informal sector of workers).

\section{Demographics}

Though less of an issue currently than for other regions of the world, Africa too will age. The United Nations estimates that by 2050 there will be almost 2 billion people over 60 worldwide, close to $80 \%$ of whom will be living in developing countries (see Chart 1). As elsewhere, the over $60 \mathrm{~s}$ - and particularly the over $80 \mathrm{~s}$ - represent the fastest growing population group on the African continent, with the numbers of older people increasing by $50 \%$ between 2000 and 2015 and nearly fivefold by 2050 (Help Age International (2006a)).

Even now one in five (an estimated over 100 million) of the world's poorest people - living on less than a dollar a day - are over 60 (van Dullen (2007)). As in other regions of the world, social pressures from urbanization and declining family size will make it harder for elderly Africans to rely on family support. Global experience shows that issues surrounding aging populations - including pensions - cannot be addressed too early and developing countries should try to use their 'demographic sweet spot', when dependency ratios are falling and before the impact of aging hits, to address these challenges.

\footnotetext{
1 The authors would like to thank Montserrat Pallares-Miralles of the World Bank for invaluable help with this Working Paper. The views expressed are the sole responsibility of the authors and do not necessarily reflect those of the OECD or its member countries. The authors are solely responsible for any errors.
} 


\section{Chart 1: Size and Distribution of World Population aged 60 years or over by groups of Countries}

Developing countries Economies in transition

Developed countries

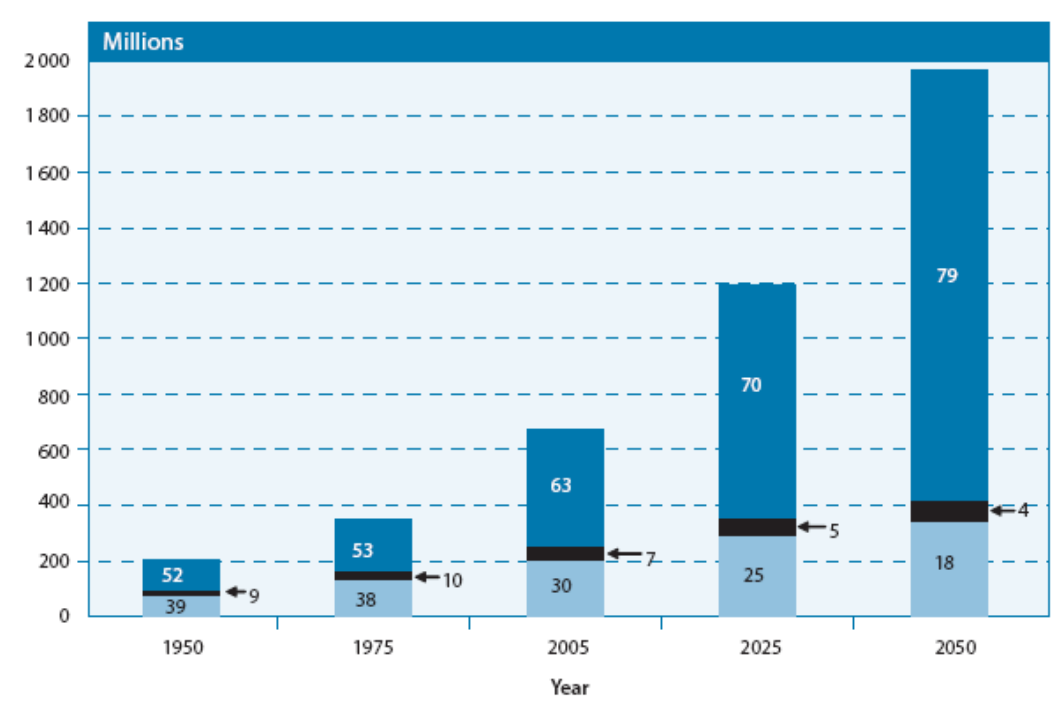

Source: United Nations World Population Prospects: The 2004 Revision, vol.I

Note: The graph shows estimates (until 2005) and medium-variant projections (after 2005). Percentages are shown inside the bars.

Chart 2: Child and old-age dependency ratios 1950-2050, developing countries

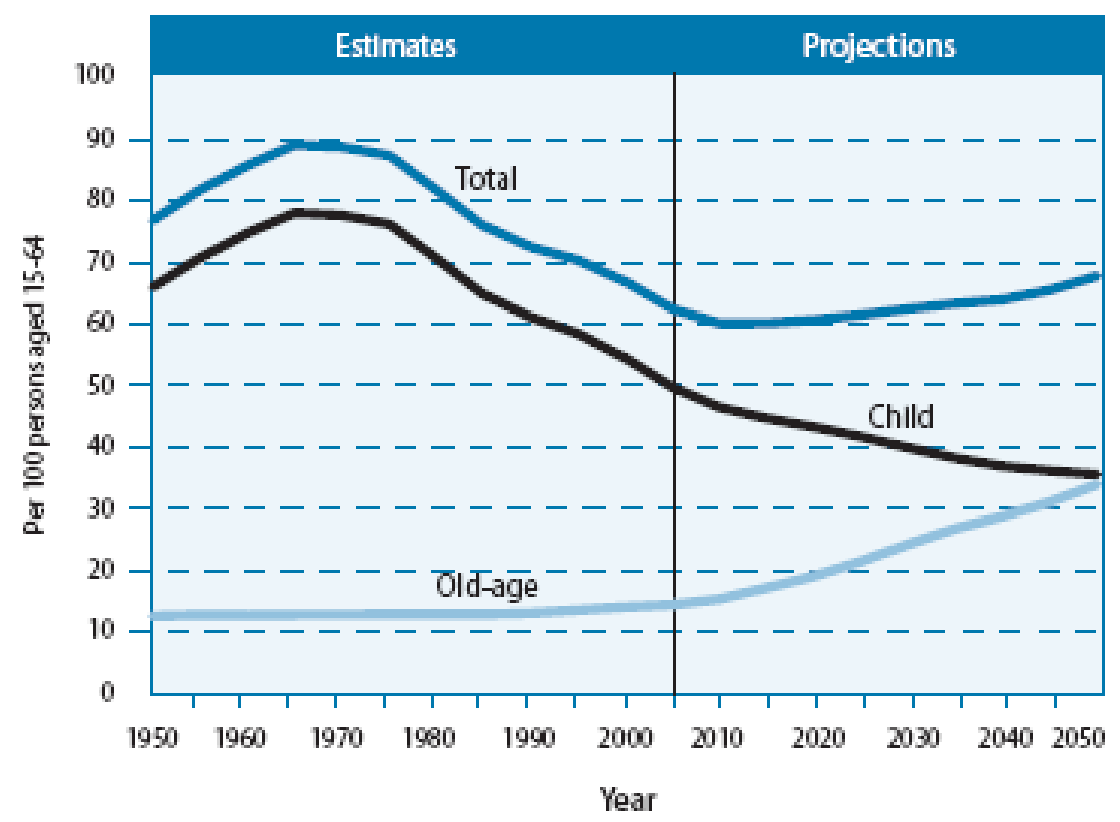

Source: UN/ DESA 


\section{Poverty Alleviation}

Pensions play an important role in poverty alleviation of the elderly - one of the most vulnerable groups in any society, particularly older women. Yet, according to the ILO, only one in five workers is covered by adequate social security schemes ${ }^{2}$, whilst the World Bank (Holtzman, Hinz (2001)) point out that $85 \%$ of the world's population over 65 has no retirement benefit at all. In sub-Saharan Africa less than $10 \%$ of the older population has a contributory pension (Palacios, Pallares-Miralles (2000)).

Basic, social support can be implemented via public pension arrangements. Indeed social protection is increasingly considered as contributing to the development process in the same way as health and education (van Dullen (2007)). It is beyond the scope of this paper to enter the debate over which type of social pension is most appropriate -contributory vs. non-contributory / universal vs. means tested etc. - (see referenced ILO and World Bank papers as an introduction to the topic). However, irrespective of the type of arrangement, in addition to reducing poverty amongst the elderly, providing pensions has also been shown to have implications for broader society, as benefits are shared with household members - for example via providing food, clothing and school materials for grandchildren.

\section{Chart 3: Pension Spending by Older People}

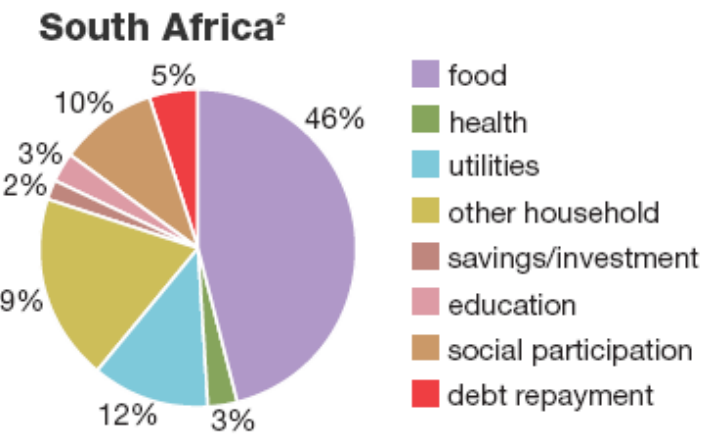

Source: Moller, Ferreira(2003)

Indeed, older persons can often act as de facto heads of household, caring for relatives infected with HIV/AIDS and looking after orphaned children. Around 30\% of households in sub-Saharan Africa are headed by a person aged 55 and over, with over two-thirds of these households including at least one child under the age of 15 (Help Age International (2006a)). Over 60\% of orphaned children in Namibia, South Africa and Zimbabwe, and 50\% in Botswana, Malawi and Tanzania, live with their grandparents (United Nations (2007)).

Receiving and sharing a pension cements intergeneration relationships and makes the elder more integrated into communities, rather than feeling like a burden on their families.. The following examples of the positive social impact which pension can have are taken from Help Age International's Social Protection Facts and Figures (Help Age International (2006b)):

- Pensions reduce the poverty gap ratio by $13 \%$ in South Africa and increase the income of the poorest $5 \%$ of the population by $50 \%$;

\footnotetext{
${ }^{2}$ Statistics quoted by Vinícius Carvalho Pinheiro, ITC - ILO at the OECD/IOPS Global Forum on Private Pensions, Istanbul, Turkey, November 2006 http://www.oecd.org/dataoecd/62/23/37696140.pdf
} 
- In South Africa, families receiving a pension are $11 \%$ less like to become poor;

- In Tanzania, where there is no pension, out of 146,000 children orphaned by HIV/AIDS, only 1,000 attended secondary school, because their grandparents could not afford the fees;

- In Zambia, a pilot cash-transfer scheme to older people caring for orphans has improved school attendance;

- In South Africa, girls living in a household with an older woman who receives a pension are 3-4 centimetres taller than girls in households with older women who do not receive a pension.

In addition the $\mathrm{ILO}^{3}$ point out that providing social pensions in Latin America has helped to reverse rural-urban migration, decrease birth mortality rates and provided much needed liquidity to households (allowing them to shift from subsistence to surplus agriculture, invest in rural production and increase consumption and provide credit for pensioners).

Examples from developing countries have shown that implementing a basic pension need not be particularly complicated or expensive, as social pensions can cost only a few percent of GDP (source of following charts see footnote 1).

\section{Chart 4: ILO Estimates Cost of Social Protection - Flat Benefit}

Is the social protection floor affordable? Cost of universal basic old age (65) and disability pension (benefit $=\$ 0.5$ per day)

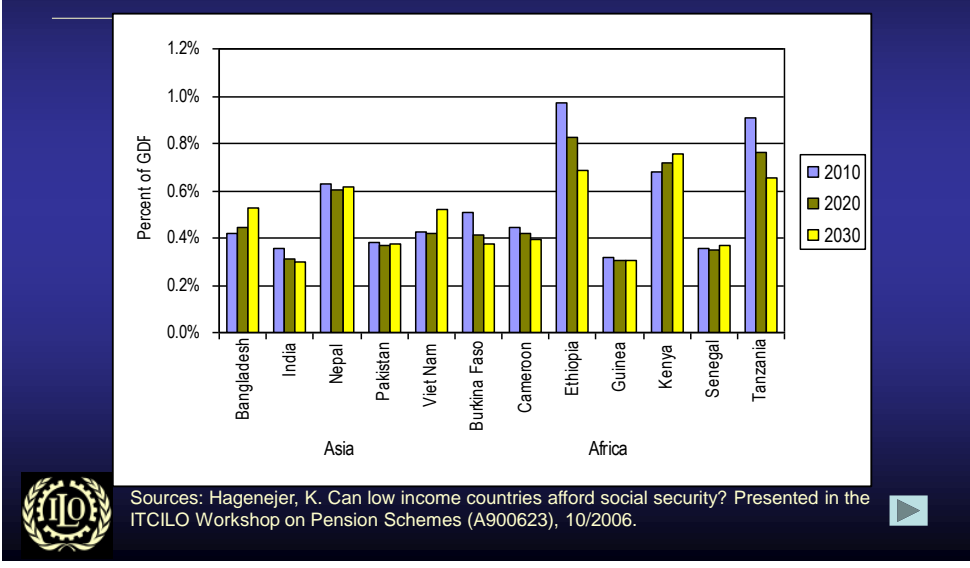

\footnotetext{
${ }^{3}$ See footnote 2.
} 


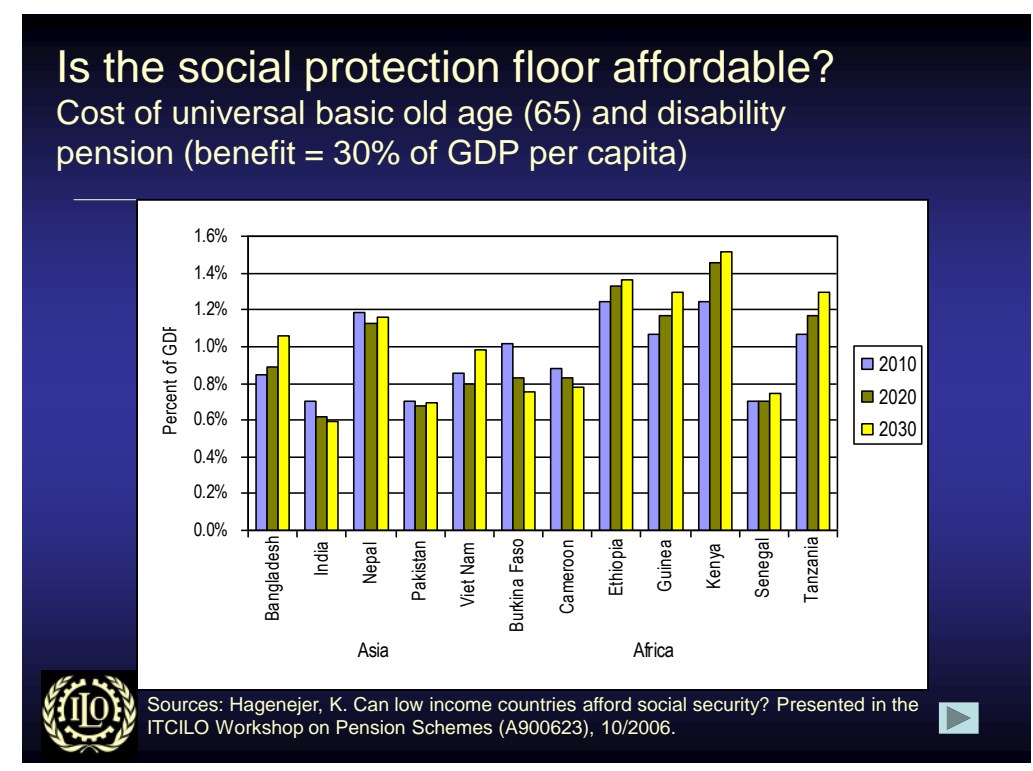

For Africa, the fiscal cost of providing a universal noncontributory social pension to all of the elderly has been estimated at 2 to 3 percent of GDP, a level comparable to, or even higher, than the levels of total public spending on health care in some countries (Kakwani and Subbarao (2005)). However, such estimates depend on parameters such as benefit levels and entitlement ages that can be adjusted in order to keep the fiscal cost manageable. That said, the debate over whether cash payment based pensions are the best way to tackle the broader social challenges mentioned needs to be considered, but is outside the scope of this paper.

\section{Alleviating Government Costs ${ }^{4}$}

In addition to social pensions being affordable for many emerging economies, developing funded pension systems can also reduce government expenditure, thereby releasing funds to direct to other key policy challenges and initiatives. The reform of unsustainable pay-as-you-go (PAYG) pension systems can help reduce the fiscal burden that such schemes place on the population, and indeed avoid burdening future generations. Such concerns are greatest in countries with high levels of labour market informality, as is the case in developing countries in Africa and elsewhere, as large groups of the population may not have access to the pension system but support it indirectly via the tax system. Spending of pensions (particularly on pensions for civil servants and other special schemes) has increased enormously in the region, and is crowding out spending on other deserving programs.

The potential for major fiscal imbalances and regressive distributional outcomes is compounded when the pension scheme is designed to cover only specific workers with a high degree of political power. In Africa this is often the case of civil servants pension arrangements. In all countries the formula used to calculate the pension for civil servants tends to be more generous than for private sector workers. The impact of a more generous formula and a more mature system along with a lack of reserves results in a build-up of large deficits that are ultimately a burden on the rest of the population, and the crowding out of other important expenditures.

\footnotetext{
${ }^{4}$ This section is taken from Yermo, J. (2008), "Governance and Investment of Public Pension Reserve Funds in Selected OECD Countries", OECD Working Papers on Insurance and PrivatePensions, No. 15, OECD Publishing. http://www.oecd.org/dataoecd/26/53/40194872.pdf
} 
To give one African example, civil servants in Uganda are cover by the public service pension scheme, run by the public service pension fund. ${ }^{5}$ Despite the name, the system is financed directly from the government budget; there are no statutory contributions. Civil servants can retire at the early age of 45 , vesting periods are only 10 years, the benefit accrual rate is $2.4 \%$ per year, the reference wage for pension calculations is the last salary and benefits are indexed to wages. A similar scheme covers staff of the armed forces. By contrast, the civil service scheme in Botswana now operates on a fully funded, defined contribution basis, with no burden on the rest of the economy except the contribution rate of the government which is transparent.

\section{Box 1: Pros and caveats of an integrated / harmonized system}

There are separate pension schemes for civil servants in about half of the world's countries, including some of the largest developing economies, such as Brazil, China and India. However, there appear to be strong arguments for integration, particularly in smaller and /or low income countries. Various countries have already followed this path. The long-term goal thus should be a single, national scheme for reasons of equity, administrative efficiency and labormarket flexibility. This does not preclude, however, additional top-up schemes designed to achieve specific human resource objectives.

The main pros of harmonizing and integrating the pension systems can be summarized as follows:

a) Labor market distortions and inequity between formal sector workers in the same country are reduced. There is no obvious reason public policies dealing with lifetime consumption smoothing or survivor's insurance should differ between public and private sectors ( except perhaps, for military personnel ).

b) With integration, duplication of administrative functions, such as recordkeeping, is not needed. To the extent that there are economies of scale in recordkeeping, payment of pensions and other activities of mandatory pension funds, with no integration, this duplication represents an unnecessary cost that ultimately reduces the financially sustainable benefit level.

c) To harmonize the pension rules of the civil servants with the ones of the national pension system would mean a reduction of pension liabilities. Indeed the fiscal implications of harmonizing can be considerable. Civil servants pension schemes offer more generous terms, tend to have lower funding ratios and have higher per member liabilities than other schemes. In many countries, civil service pensions are becoming a major fiscal burden, threatening to crowd out other programs, especially in low-income countries with limited tax bases. With harmonization and integration fiscal liabilities decrease.

The main caveats that need to be considered with integration can be summarized as follows:

a) Integration may involve a new budget outlay, as the government makes its employer contributions to a parastatal institution. It is important therefore to estimate the path of transition financing and determine the pace of the integration accordingly.

b) A rapid integration will imply higher transition financing needs but will eliminate some of the distortions of dualism more quickly. On the other hand, a slower transition, for example, one wherein only new hires were obliged to join the national pension scheme, would be easier to accommodate in the short run, easier to administer and more politically palatable. Slow transitions would, however, allow distortions to persist for decades and would not go as far in improving the long term fiscal situation.

c) It is very important to look at the adequacy and sustainability of the national scheme into which civil servants would be integrated.

Clearly reforms to the two schemes should be linked. Parametric reforms to the civil service scheme that are phased in over time can reduce the disparities between the two and make integration easier. Reforms that increase the solvency and credibility of the main national scheme increase the benefits from integration. In short, pension system reform should, to the extent possible, be holistic.

\footnotetext{
${ }^{5}$ For a full description of the scheme, an analysis of its sustainability and proposals for reform see Bogomolova et al. (2006), An Assessment of Reform Options for the Public Pension Fund of Uganda, World Bank Policy Research Working Paper 4091, December 2006.
} 


\section{Macroeconomic benefits of prefunding pensions}

Many countries around the world are partly prefunding their otherwise pay-as-you-go (PAYG) financed social security systems by establishing or further developing existing public pension reserve funds (PPRFs). This trend is parallel to the growing shift towards fully-funded, privately managed pension systems, which has in turn heightened the role of pension funds in retirement income arrangements. Though benefits of prefunding have been found in other regions, which the preconditions exist to allow such rewards to be enjoyed in many African countries may be debated.

Prefunding pensions, whether it is via the establishment of public pension reserve funds or the development of fully-funded, private pension systems can help governments respond more effectively to the fiscal pressures that will result from ageing populations. While prefunding may not in itself offset the decline in domestic growth rates that may result from worsening dependency ratios, it can help to solvent some aspects of the demographic shock. In particular, prefunding social security systems can facilitate taxsmoothing, that is, maintaining relatively constant contribution rates to the social security system. While such objectives could also be met by appropriate management of the public debt, assets in the reserve fund are assigned to financing the social security system. Savings in the form of public debt reductions, on the other hand, may end up being used for other future outlays of the government.

Prefunding pensions can also serve important macroeconomic goals:

- $\quad$ Raise national savings: In the case of public pension reserve funds, a legal commitment to use reserve fund assets exclusively for future pension expenditures and to invest in a diversified manner forces the government to reduce current expenditure or raise taxes to maintain current fiscal objectives. Hence, public saving will rise and the overall debt position of the government may improve. If a private pension system is introduced, as long as there is not a perfect substitution between pensions and other forms of saving, total private sector saving will be raised. The impact on savings is greatest if the system is made mandatory.

- International diversification: by establishing reserve funds or pension funds a country is better able to access output produced in foreign countries which may not be suffering the same demographic and economic shocks, raising national welfare.

- Financial market development: In developing countries, where financial systems are underdeveloped, prefunding pensions may contribute to economic growth by improving access to finance for productive activities. Pension funds and other institutional investors can also help improve the operation of financial markets by making markets more liquid, efficient and transparent by for example, encouraging the modernisation of market trading and engaging in shareholder activism. They can also act as a countervailing force to commercial banks and stimulate financial innovation. However, a high and sudden demand by pension funds for local assets could have a distorting impact, and therefore should be managed with care.

While it is difficult to quantify such macroeconomic effects and isolate them from other factors, the few studies that have attempted to do so have found relatively large effects especially for the Latin American region, the pioneer among the developing world in prefunding pension systems (see Box 2). 


\section{Box 2. Empirical evidence on the macroeconomic impact of pension prefunding.}

One the most researched cases is the Chilean one, which reformed its pension system in 1981 by replacing its social security system with a mandatory individual account system run by privately managed pension fund administrators. Lefort and Walker (2002) found evidence of a positive impact of pension fund equity investment on the cost of capital of firms as proxied by price-to-book ratios and dividend yields. Corbo and Schmidt-Hebbel (2003) find evidence of a direct impact of pension reform on total savings and hence on economic growth. They estimate that approximately half of the increase in total savings between 1981 and 2001 (4.9 percent of GDP) was due to the pension reform. They also estimate that the pension reform explains 20 percentage points of the 1 percent growth in Total Factor Productivity (TFP) growth over the period (as a result of financial development) and 0.5 percentage points of the 4.6 growth in real GDP over the period.

For other countries, the evidence on the impact on savings, financial market development and growth is mixed, but generally positive, especially as far as developing countries are concerned. López Murphy and Musalem (2004) show that the introduction of mandatory funded pension systems contributed to higher savings in a sample of developing countries that they analyse.

Various studies have focused on the impact of pension funds on the development of financial markets. Catalan et al. (2000) show that pension funds and other institutional investors have contributed to the development of equity markets and in particular explain the size of the stock market vis-à-vis banks. Impavido et al. (2003) however find little evidence of a relationship between contractual savings (pension funds and life insurance companies) on a crosssection of countries and an indicator of trading activity (traded values relative to GDP). The link is stronger for developing countries and for developed countries with bank-based financial systems.

Some recent studies have also looked at the direct link between the growth of pension funds and economic growth. Davis (2002) finds a significant direct effect of the share of equities held by pension funds and life insurance companies on TFP growth in 16 OECD countries. Davis and Hu (2004) using a dataset covering 38 countries also find a direct positive link between pension assets and the growth of output per worker. Both papers argue that an important aspect of the financial development channel is an enhancement of corporate governance. Even firms unaffected by shareholder activism, they conclude, have natural incentives to improve their performance so as to avoid the threat from pension fund activism in the future.

In Africa, infrastructure is one of the most promising venues for pension fund investment. So far, the most active investors have been pension funds in South Africa, but pension funds in other countries are also looking into the asset class. For example, Kenya is looking to the pensions industry to fund the country's infrastructure and domestic needs in partnership with the International Finance Corporation (IFC) and World Bank. The government announced in 2007 that it would issue asset-backed securities to pay for roads and housing under the 2006 initiative Efficient Securities Markets Institutional Development (ESMID) Africa, a $\$ 5.5 \mathrm{~m}$ with funding from IFC/World Bank, OMX and the Swedish Government. However, a clear distinction needs to be drawn between investment and simple expenditure, as pension funds in the region have previously been used to fund all manner of generic construction and other projects which make limited contributions to development and growth. As OECD guidelines stress, governance of infrastructure projects is key in all parts of the world ${ }^{6}$.

Two important questions for African countries wishing to introduce funded pensions are firstly, what form should such prefunding take and, secondly, what are the preconditions for ensuring that the much desired macroeconomic effects actually take place?

Around the world, countries have chosen different routes to prefund pension systems. Many OECD countries have recently established reserve funds, which complement a long tradition of pension fund

\footnotetext{
${ }^{6}$ See OECD Principles for Private Sector Participation in Infrastructure www.oecd.org/daf/investment/ppp For further background information relating to the Principles see www.oecd.org/daf/investment/ppp
} 
provision. The situation varies widely across non-OECD countries. In Latin America and most countries in Eastern Europe, pension funds have been recently established, partly replacing the PAYG financing system. This is leading to a rapid accumulation of funds in these countries. In addition, a few non-OECD countries, primarily in Asia, have relatively large reserve funds that support their social security systems, but a rather small pension fund sector (e.g. include China, Egypt, Jordan, Philippines and Saudi Arabia).

In general, prefunding via pension funds is preferable to reserve funds, as the former guarantee ownership or beneficial rights to pension plan members and are normally subject to a comprehensive regulatory and supervisory framework. Moreover, the financial advantages of prefunding generally apply whether this takes place via pension funds or reserve funds. A preference for reserve funds may arise if there are cost or/and investment performance advantages over privately managed pension funds, something which is unlikely to happen in countries with poor public sector governance. The governance of public pension reserve funds can be strengthened in such countries if they are given complete investment management autonomy and quasi-private status, as governments in Australia, Canada, and New Zealand have done with their public pension reserve funds.

A second question for African countries to consider is whether there are any conditions to ensure that the introduction of prefunding creates the macroeconomic benefits of the kind observed in Chile. It should be stressed that many countries in Africa are not in the position which the Latin American countries were when they introduced their pension reforms. As far as financial market development is concerned, three basic requirements are macroeconomic stability, the establishment of an appropriate regulatory and supervisory framework for the funded pension system, and the availability of custody, credit rating and other auxiliary services that pension funds rely on for their investments. The latter can be expected to be accessible internationally in today's global financial markets, so their absence in the local market should not be an impediment for introducing some form of prefunding.

Macroeconomic stability and low inflation are important because neither financial markets nor institutional investors can function effectively in situations of financial instability, such as those triggered by large fiscal deficits and high and volatile inflation.

The development of an appropriate regulatory and supervisory regime is also essential but may be a complex task for some developing countries. The investment rules in place in some Latin American countries, for example, have been designed in such a way which has not been conducive to growth in the local stock market as pension funds are forced to invest largely in government bonds. While quantitative investment restrictions may be necessary in the early years of a new system, it is important that such rules are gradually relaxed over time in order to benefit from the diversification of investments and their positive impact on the domestic economy. African countries intending to establish funded pension systems should consider reviewing the OECD's and IOPS' respective principles on the regulation and supervision of private pensions.

\section{Pension Systems in Africa}

Most sub Saharan African countries do not have meaningful publicly managed pension and social security systems, though some form of pension coverage is available in a limited number of countries. Where benefits are offered to formal sector workers, they are provided either by pubic service pension schemes (the public sector being by far the largest employer in most countries the region), national (usually mandatory) schemes covering private sector workers (which may also cover the public sector), occupational schemes managed by employers other than the government and individual / personal pension schemes (usually offered by insurance companies on a voluntary basis). 
For example, universal pension systems operate in Botswana, Mauritius and Namibia, whilst a means tested public pension is available in South Africa. Social pensions also operate in Lesotho and Senegal, whilst occupation pensions are available, albeit for a limited percentage of the population, in countries such as Nigeria and Kenya. However, it should be noted that the majority of people in the region work in the informal sector and are therefore not covered by these schemes, implying that they rely on informal arrangements and their own/ family resources.

Chart 6: Coverage: Percentage of over 60s receiving a social pension

Source: Help Age International

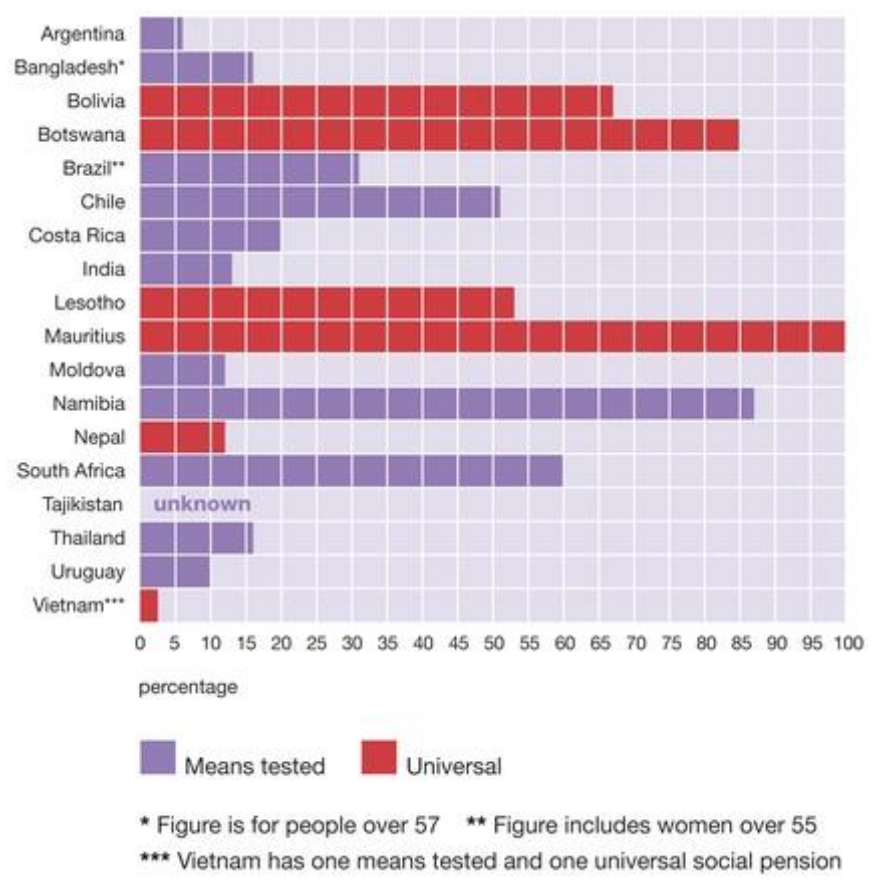

Table 1: Types of Social Security Programmes and Systems for Retirement Income

\begin{tabular}{|l|c|c|c|c|l|l|l|}
\hline & $\begin{array}{l}\text { Old Age, } \\
\text { disability and } \\
\text { survivors }\end{array}$ & $\begin{array}{l}\text { Earnings- } \\
\text { related }\end{array}$ & $\begin{array}{l}\text { Means- } \\
\text { tested }\end{array}$ & $\begin{array}{l}\text { Flat-rate } \\
\text { Universal }\end{array}$ & $\begin{array}{l}\text { Provident } \\
\text { Funds }\end{array}$ & $\begin{array}{l}\text { Occupational } \\
\text { Retirement schemes } \\
\text { Voluntary = V } \\
\text { Mandatory = M }\end{array}$ & $\begin{array}{l}\text { Personal } \\
\text { Retirement schemes } \\
\text { Voluntary = V } \\
\text { Mandatory = M }\end{array}$ \\
\hline Benin & $\mathbf{X}$ & $\mathbf{X}$ & & & & & \\
\hline Botswana' & $\mathbf{X}$ & & & $\mathbf{X}$ & & & \\
\hline Burkina Faso & $\mathbf{X}$ & $\mathbf{X}$ & & & & & \\
\hline Burundi & $\mathbf{X}$ & $\mathbf{X}$ & & & & & \\
\hline Cameroon & $\mathbf{X}$ & $\mathbf{X}$ & & & & & \\
\hline Cape Verde & $\mathbf{X}$ & $\mathbf{X}$ & & & & & \\
\hline $\begin{array}{l}\text { Central } \\
\text { African } \\
\text { Republic }\end{array}$ & $\mathbf{X}$ & $\mathbf{X}$ & & & & & \\
\hline Chad & $\mathbf{X}$ & $\mathbf{X}$ & & & & & \\
\hline $\begin{array}{l}\text { Congo } \\
\text { (Brazzaville) }\end{array}$ & $\mathbf{X}$ & $\mathbf{X}$ & & & & & \\
\hline $\begin{array}{l}\text { Congo } \\
\text { (Kinshasa) }\end{array}$ & $\mathbf{X}$ & $\mathbf{X}$ & & & & & \\
\hline Cote d'lvoire & $\mathbf{X}$ & $\mathbf{X}$ & & & & & \\
\hline Equatorial & $\mathbf{X}$ & $\mathbf{X}$ & & & & & \\
\hline
\end{tabular}




\begin{tabular}{|c|c|c|c|c|c|c|c|}
\hline Guinea & & & & & & & \\
\hline Ethiopia & $\mathbf{X}$ & $\mathbf{X}$ & & & & & \\
\hline Gabon & $\mathbf{X}$ & $\mathbf{X}$ & & & & & \\
\hline Gambia & $\mathbf{X}$ & $\mathbf{X}$ & & & $\mathbf{X}$ & & \\
\hline Ghana & $\mathbf{X}$ & $\mathbf{X}$ & & & & & \\
\hline Guinea & $\mathbf{X}$ & $\mathbf{X}$ & & & & & \\
\hline Kenya & $\mathbf{X}$ & & & & $\mathbf{X}$ & $\mathbf{V}$ & $\mathbf{V}$ \\
\hline Liberia & $\mathbf{X}$ & $\mathbf{X}$ & $\mathbf{X}$ & & & & \\
\hline Madagascar & $\mathbf{X}$ & $\mathbf{X}$ & & & & & \\
\hline \multicolumn{8}{|l|}{ Malawi $^{2}$} \\
\hline Mali & $\mathbf{X}$ & $\bar{X}$ & & & & & \\
\hline Mauritania & $\mathbf{X}$ & $\mathbf{X}$ & & & & & \\
\hline Mauritius & $\mathbf{X}$ & $\mathbf{X}$ & & $\mathbf{X}$ & & & \\
\hline Namibia $^{5}$ & $\mathbf{X}$ & & & $\mathbf{X}$ & & $\mathbf{V}$ & $\mathbf{V}$ \\
\hline Niger & $\mathbf{X}$ & $\mathbf{X}$ & & & & & \\
\hline Nigeria & $\mathbf{X}$ & & & & & $\mathbf{M}$ & \\
\hline Rwanda & $\mathbf{X}$ & $\mathbf{X}$ & & & & & \\
\hline $\begin{array}{l}\text { Sao Tome } \\
\text { and Principe }\end{array}$ & $\mathbf{X}$ & $\mathbf{X}$ & & & & & \\
\hline Senegal ${ }^{3}$ & $\mathbf{X}$ & $\mathbf{X}$ & & & & & \\
\hline Seychelles & $\mathbf{X}$ & $\mathbf{X}$ & & & & & \\
\hline Sierra Leone & $\mathbf{X}$ & $\mathbf{X}$ & & & & & \\
\hline South Africa ${ }^{4}$ & $\mathbf{X}$ & & $\mathbf{X}$ & & & V & $\mathbf{V}$ \\
\hline Sudan & $\mathbf{X}$ & $\mathbf{X}$ & & & & & \\
\hline Swaziland & $\mathbf{X}$ & $\mathbf{X}$ & & & $\mathbf{X}$ & & \\
\hline Tanzania & $\mathbf{X}$ & $\mathbf{X}$ & & & & & \\
\hline Togo & $\mathbf{X}$ & $\mathbf{X}$ & & & & & \\
\hline Uganda & $\mathbf{X}$ & & & & $\mathbf{X}$ & & \\
\hline Zambia & $\mathbf{X}$ & $\mathbf{X}$ & & & & V & \\
\hline Zimbabwe & $\mathbf{X}$ & $\mathbf{X}$ & & & & $\mathbf{V}$ & \\
\hline
\end{tabular}

Source: ILO (See Appendix 1 for definitions)

Notes: 1 Botswana (old age + orphans) 2 Malawi no mandatory system for retirement income

3 Senegal (old age + survivor) 4 South Africa (survivor benefits mostly provided by unemployment)

5 Namibia - source authors 
Table 2: Relative Importance of Segments in the Financial Systems of Selected African Countries (\% of total assets of the system, latest available data ${ }^{1}$ )

\begin{tabular}{|c|c|c|c|c|c|c|c|}
\hline Country & $\begin{array}{l}\text { Commerical } \\
\text { Banks }\end{array}$ & $\begin{array}{l}\text { Other (mainly) } \\
\text { Deposit-taking } \\
\text { Institutions }\end{array}$ & $\begin{array}{l}\text { Microfinance } \\
\text { Institutions }\end{array}$ & $\begin{array}{l}\text { Rural } \\
\text { Banks }\end{array}$ & $\begin{array}{l}\text { Insurance } \\
\text { Companies }\end{array}$ & $\begin{array}{l}\text { Pension } \\
\text { Funds }^{2}\end{array}$ & Other \\
\hline Botswana & 40 & & & & 1.6 & 17.4 & $6.8^{3}$ \\
\hline $\begin{array}{l}\text { Central } \\
\text { African } \\
\text { Republic }\end{array}$ & 68.5 & 34.4 & 2.7 & & 7.6 & 21.1 & \\
\hline Comoros & 94 & & 6 & & & & \\
\hline $\begin{array}{l}\text { Congro, Rep. } \\
\text { of }\end{array}$ & 89.8 & & 7 & & 3.2 & 3 & \\
\hline Ethiopia & 88.4 & 3 & & & 3 & & $5^{4}$ \\
\hline Gabon & 83.6 & 4.8 & & & 7.8 & & $5^{5}$ \\
\hline Gambia & 97 & & 1 & & 2 & & \\
\hline Ghana & 50.9 & 6 & & & 2 & 15.1 & \\
\hline Guinea & 98.2 & 1.8 & 1.8 & & & & \\
\hline Kenya & 60.4 & 15 & 0.5 & & 8.2 & & \\
\hline Lesotho & 91.8 & & & & 7.8 & & \\
\hline Madagascar & 97.8 & 0.6 & 1.6 & & & & \\
\hline Malawi & 70.9 & 17.5 & & & 29.1 & & \\
\hline Mali & 98.7 & & & & & & \\
\hline Mauritius & 94.8 & 4.4 & & & & & \\
\hline Mozambique & 94.9 & 4.3 & 0.1 & & & & \\
\hline Namibia & 38.1 & & & & 24.8 & & \\
\hline Niger & 61.9 & 1.1 & 1.7 & 0.7 & 7.6 & & \\
\hline Nigeria & 90.5 & 8.12 & & & 2.1 & 0.6 & \\
\hline Rwanda & 53 & 2.6 & 4.5 & & 4.3 & 20.6 & \\
\hline Senegal & & & 2.6 & & & & \\
\hline Seychelles & 87.1 & 6 & & & 2.1 & 5 & \\
\hline South Africa & 25.3 & & & & 14.6 & & \\
\hline \multicolumn{8}{|l|}{ Swaziland } \\
\hline Tanzania & 78 & & & & 4 & 13 & \\
\hline \multicolumn{8}{|l|}{ Uganda } \\
\hline Zambia & 59.6 & 23 & 0.2 & & 3.8 & 16.7 & \\
\hline Zimbabwe & 76.6 & 10.2 & 0.1 & & 3 & 2 & \\
\hline
\end{tabular}

Source $\mathrm{IMF}^{7}$

Notes: 1 Numbers do not always add up to $100 \%$

2 In most countries state pension funds

3 Capital / investment funds

4+ 5 Development Bank

${ }^{7}$ http://www.imf.org/external/pubs/ft/wp/2007/wp0718.pdf 
An increasing number of African countries have recently initiated major parametric and systemic reform of their pension systems (often on the initiative of stakeholder, advisory committees and international organisations) and are beginning to adopt diversified approaches to pension provision in order to strengthen retirement security of their workforce. Many other authorities are in the process of formulating serious reform proposals and are exploring ways to encourage more saving over the long run.

In Africa, although the problems of the schemes that cover private sector workers have become increasingly evident, the motivation for reform has come more frequently from the fiscal pressures of civil service pensions (usually much more generous systems). In several countries, the need to address this short-term fiscal issue has led policy makers to reconsider overall pension policy. In particular, the alternatives to the current arrangements for civil servants include a new system that replaces the dualism with one in which all formal sector workers participate. Although it is still politically very difficult, a few countries have already considered and even implemented 'integration' of their pension systems (as discussed in Box 1). Reform is also being driven by an increasing awareness of old age provision as an integral part of social policy, fixing unsustainable existing schemes and making them more efficient in terms of administrative costs and returns (following serious mismanagement in some countries), as well as the desire to increase savings and develop financial markets in the region.

The structure and challenges to the pension systems in each country differ, with countries correspondingly adopting different reform agendas. The pace of reform also differs from country to country, ranging from the introduction of individual DC accounts in Nigeria, to extending pension coverage to the informal sector in Botswana; exploring ways to overhaul the civil service pension scheme in Kenya; to improving pension fund governance and reforming taxation of retirement funds in South Africa. Many countries - including Botswana, Kenya, Zambia - are reviewing their national social security and severance schemes to make them less expensive to administrate and more sustainable for retirees in the long run.

A major component of these announced reforms is the need to improve the quality and effectiveness of the supervisory oversight of the burgeoning pension system. In most countries pension and social security institutions are not regulated and supervision is fragmented and weak. Countries such as Zambia and Kenya continue to establish their pension fund regulation, whilst new supervisory authorities have been created in countries such as Botswana.

The challenges of systemic reform, where there is a shift from unfunded to funded schemes and possibly the introduction of private management of assets, are particularly great in Sub-Saharan Africa. Reformers face three major obstacles:

a) First and foremost, any diversion of contributions to a new funded scheme will force governments to find resources to covers the resulting gap. Since most of the countries depend heavily on foreign aid to supplement their budgets, there is little scope for financing the transition, at least not a rapid transition.

b) Second, existing public pension institutions are generally not equipped to meet the recordkeeping requirements of a funded individual accounts scheme.

c) Finally, few of the conditions that make a privately managed, funded system viable -investment opportunities, solid regulatory institutions, and potential participants in the private pension sector -are present in most of the region. 


\section{Overviews of Selected Countries}

\section{Botswana,}

A universal, Old Age Pension System, was initiated in Botswana in 1996. Coverage extends to all citizens over 65 years of age residing in Botswana. The costs are born by the government, with 220 pula month provided in benefits, adjusted periodically according to changes in the cost of living.

The fund public sector employees scheme - the Botswana Public Officers Pensions Fund (BPOPF) was reformed in 2001, moving from a DB to a DC arrangement. The fund has experienced strong growth as most public servants exercised their option to join the fund.

Occupational pensions are also growing, with assets having reached the current market value of around P33 billion. ${ }^{8}$ Of Botswana's 790,000 labour force, around 300,000 are in private, formal employment. Yet $84 \%$ of these workers do not have any occupational pension coverage, with around $33 \%$ of public sector workers also not covered, and there is little evidence of supplementary saving in individual products to close this gap (Genesis Analytics (forthcoming)).

A gratuity / severance scheme also exists in Botswana, with employers required to make a cash payment on the 5th anniversary of an employee's term of employment, and similar payments, at double the rate, at the end of every 5 years thereafter, with eligibility for pro-rata cash benefits on termination of employment. However, employers are not required to pre-fund these obligations, they often do not comply and the payments are not generally used to fund retirement income.

The government in Botswana is looking to reform their system, to increase administrative efficiency and sustainability. A Non-Bank Financial Authority has been created which oversees the pension fund industry.

\section{Cap Verde}

There are two contributory pension schemes for formal sector workers in Cape Verde. The "Administração Pública" (AP) scheme, which, according to the civil service census, has an estimated 14,600 contributors (i.e., police, teachers, and other civil servants), and the "Instituto Nacional de Previdência Social" (INPS), which covered approximately 36,400 private sector workers in 2004. The INPS is the National Social Security Institute of Cape Verde created in 1983 to administrate a compulsory social security scheme (not only covering pensions, but health benefits, family allowances and maternity benefits) for dependent workers in the private sector. The institution was designed to be self-financing through social contributions and investments. However, as a National Institute, the State is ultimately responsible for the provision of benefits and for the proper administration of the programs.

The integration of civil servants into the INPS has been under discussion for a few years and in February 2006 a new integration law was approved to be implemented when the budget will be approved in 2006. Even though, in consolidated terms, there is a gain in moving civil servants to the INPS system, as it provides fewer benefits, the integration worsens the unsustainability of the INPS. Preliminary estimates indicate that the INPS system will be in deficit around 2040, as the system matures and the demographic situation improves. Now is the time to proceed with further reforms in order to avoid a deficit in 2040. Reforms must consider either a raise in the contribution rates or a substantial cut in benefits. Regarding the AP (Public Administration) there is a possibility of making the transition less costly by a combination of a lower accrual rate, later retirement, and price indexation of benefits. Regarding the

\footnotetext{
${ }^{8}$ http://allafrica.com/stories/200711081005.html
} 
INPS, one possibility would be increasing the contribution rates at an earlier point than when reserves are exhausted.

Together, both the AP (for civil servants) and the INPS (for private sector workers) cover one quarter of Cape Verde's labor force and pay pensions to about 7,300 people. There are also three non-contributory pension schemes. The "Pensão Social Mínima" (PSM) is a social assistance scheme that pays benefits to approximately 5,000 elderly individuals that meet income and age criteria established under a 1995 law, the "Pensão de Solidaridade" is paid to more than 9,000 former FAIMO workers over age 60 subject to a (vague) income test and an eligibility condition of having worked for, at least, ten years under the program. The "Pensão de Estado" is paid to individuals with relevant contributions to the arts, culture, and independence movement of Cape Verde and covers the residual population.

The AP is a more generous pension scheme than the INPS. The AP pension plan has a retirement age for teachers and police of 55 for both male and female and 60 for other members while the retirement age is 65 for the INPS for men and 60 for women. This is particularly important as about half of the civil servants in Cape Verde are teachers, which, along with the police, are covered by the AP pension scheme. As for the basic and accrual replacement rates9 there are no major differences between the two pension schemes, but the maximum replacement rate is 20 percentage points higher in the AP than in the INPS. Moreover, while for the AP the number of years considered for the wage base calculations is only one year for both old-age and invalidity retirement, for the INPS system it is 5 years for invalidity and 10 years for old-age. Finally, total contribution rates, as a percentage of wage bill, are 15 percentage points higher in the INPS than in the AP. These differences make the AP system a more paternalistic one, which provides enrolled individuals more benefits than those granted by the INPS.

\section{Gambia}

Current pension schemes in The Gambia are: (i) the Public Service Pension Scheme (PSPS) which covers government employees (civil servants and uniformed services); (ii) special provisions for National Assembly members, Local Government Authority employees and District Chiefs; (iii) the Federated Pension Fund (FPF) which covers non-government public sector employees; (iv) the National Provident Fund (NPF) which covers private sector employees; and (v) a number of registered Occupational Schemes. The Social Security and Housing Finance Corporation (SSHFC) manages the FPF, the NPF and other housing finance schemes.

An estimated 135,000 workers - a majority of the estimated size of the formal sector labor force participate in mandatory pension schemes and of these about 18,700 are members of the PSPS and the remainder are in private sector schemes. However, given the importance of agriculture and the informal sector in the Gambian economy, the coverage rate in terms of the estimated total labor force is only about 20 percent. Active members of the PSPS represent about 14 percent of workers covered by all mandatory pension schemes, about 2.8 percent of the estimated size of the labor force and 1.2 percent of the Gambian population. The benefit structure and qualifying conditions are similar for the PSPS and the FPS. Yet while these schemes share such similarities, there is no mechanism that we are aware of to facilitate mobility of workers and portability of accrued rights between the public sector schemes.

Pension benefits are a key part of the remuneration package for civil servants, the military and police in The Gambia. Such deferred compensation is an essential part of the incentives to recruit, retain, motivate and reward public servants. In this way, an assessment of the PSPS cannot be isolated from a broader assessment of overall public servant compensation and other incentives for public officials. This is of particular importance in The Gambia given the anticipated Civil Service Reform Program. 


\section{Ghana}

There are currently two mandatory pension schemes in Ghana: the Social Security and National Insurance Trust (SSNIT), which is the main system and covers employees in the private sector, civil and public servants, professionals, traders, artisans, farmers and self-employed; and a small scheme, which is currently phasing-out, and only covers military, police, and a few civil servants, but used to cover all civil servants in the past. This last system is called originally CAP 30 program. In the aggregate both systems cover less than 10 percent of the labor force in Ghana, and cost already around 1.5 percent of GDP.

SSNIT was established by PNDC law 247 (Social Security Law, 1991), which converted a Provident Fund dating from 1972 into a pension scheme (partially-funded PAYG). The institution provides old-age pensions, invalidity, and death benefits. The current pension program has elements of defined benefit, and defined contribution. Pensioners have the right to obtain 25 percent of their pensions as lump-sum payments at the moment of retirement, and almost 30 percent of members that reach retirement age and are 'covered' by the system, do not qualify for the defined benefit component of the pension program (they receive instead lump-sum payments, as refunds of their past contributions with a determined interest).

The system's revenues largely consists of contributions from workers ( 5 percent of earnings), and employers on behalf of workers (12.5 percent of their payroll), however a fund for short-term benefits (health fund) takes 2.5 percent of the salary (out of this 17.5 percent, leaving only 15 percent for the pension fund ).

According to early work in Ghana and the White paper on pension, the formal sector is still low. The main weaknesses of the current system can be summarized as follows:

- Inadequate investment returns

- Very low coverage

- High administrative costs and low efficiency

- Substantial slippage in real value of the pensions

In response to workers' protests, a Presidential Commission on Pension was established in August 2004. The Commission was in charge to examining the pension arrangements and to make appropriate recommendations for a sustainable pension scheme (s) that would ensure retirement income security for Ghanaian workers, with special reference to the public sector. The Commission consists on a Chairman and eight members, from various sectors. The Commission presented a progress report in November 2004, an Interim report in June, 2005 and the final report in March, 2006 to the President. The Government shares the view of the Commission that to ensure retirement income security for all Ghanaian workers, the ultimate goal is the creation of a unified pension structure.

Given the inadequate current pension schemes, the Government accepted the Commission's recommendation for a contributory three-pillar pension structures, comprising two mandatory schemes and a voluntary one, as follows:

- $\quad$ First pillar. A mandatory basic state social security scheme to be administered by a restructured SSNIT, which will pay only periodic monthly and other pension benefits (such as survivors and invalidity benefits). It will be a defined benefit scheme, benefiting from a portion of contributions paid to SSNIT by both the employee (5 percent), and the employer (12.5 percent). Under this new scheme, SSNIT will no longer pay the earlier mentioned 25 percent gratuity lump-sum. 
- Second pillar. A mandatory, privately-managed occupational pension scheme. It will be a defined contribution pension scheme, paying mainly lump-sum benefits with a flexibility that allows the contributor to purchase additional annuities to enhance monthly pension benefits. The contribution rate will be 5 percent, out of this, 4 percent will be hived off SSNIT, while the remaining 1 percent will be contributed by the employer and the employee in equal proportions.

- Third pillar. A voluntary private pension scheme, offering attractive tax incentives. This would be operated in line with the provisions of the Long-Term Savings Act (LTSA), 2004.

A proposed Pension Regulatory Authority should, within five years after coming into effect of the new pension structure, achieve unification of all pension schemes in the country. With the coming into effect of the new pension scheme (estimated for the end of 2008), all workers currently on the SSNIT scheme and below 55 years, should automatically join the new scheme.

In short, the current pension system in Ghana is about to start a transition towards the new three pillar pension structure. Some of the proposals for such structure are still under revision. The new system should also ensure that it minimizes labour market distortions, and that the system is adequate, affordable, sustainable, robust, and equitable.

\section{Kenya}

The retirement benefits sector in Kenya is composed of the civil service scheme, the National Social Security Fund (NSSF), occupational schemes and individual pension schemes, with a coverage rate of around $15 \%$ of the workforce $(10 \%$ or 800,000 members of the NSSF, $3 \%$ in the civil service scheme in $1.5 \%$ occupational schemes and $0.5 \%$ covered by individual retirement benefit schemes).

The NSSF is a public provident fund established under an Act of Parliament. It covers employed persons, traders, the self-employed and, since 2004, some workers in the informal sector. It is mandatory for all employers with at least 5 employees to enroll their members, but open to all other individuals mentioned above. Members of the scheme contribute 5\% of monthly earnings up to a maximum of 200 shillings a month, which is the contribution rate for those earning more than KShs. 4,000. Employers pay $5 \%$ of payroll, with subject to a maximum of KShs. 400. Self-employed persons contribute $5 \%$ of their monthly earnings, with no minimum or maximum earning limits for contribution purposes. With effect from June 2007, members of NSSF can top up their savings at any point in time with any amount that is less than or equal to KShs. 1,000. Old-age pension benefits are available to those aged 55 who have retired from insured employment. They are available at age 50 if the person is not in insured employment. New and existing retirees can receive their benefits as a lump sum.

The Civil Service Pension Scheme covers all members of the Civil Service, and is established under an Act of Parliament as a PAYG system. It is currently non-contributory, although plans are underway to make it a contributory system.

Voluntary, occupational pension plans can be administered through pension funds or provident funds, and through DB or DC arrangements. An employer or a group of employers may, on a voluntary basis, establish a complementary occupational pension plan for their employees. Most plans are established by one single employer. Membership to an occupational pension or provident plan is often compulsory for covered employees. Once an employee decides to become a member, however, withdrawal from membership while being employed by the same employer is not allowed. Employees who are within five years of the plan retirement age when they commence work with the employer or when a new plan is established are not eligible for membership in the case of DB plans. 
There are no legal rules for employee or employer contribution levels. A typical plan requires employees to contribute at a rate of 5\% of salary and employers to contribute 10\%. Employees must be allowed to pay additional voluntary contributions to the plan without any limit (although contributions are only tax-deductible up to a limit). The total of employee and employer contributions is tax-deductible up to the limit of the lower of KShs20,000 shillings or 30\% of salary. All investment income earned by taxregistered retirement benefits schemes is tax-free.

Plans can be Defined Benefit or Defined Contribution in nature (around 80\% are DC). The age at which benefits become available is not regulated and must be laid down in plan rules. Upon attainment of the retirement age, provident plans pay out a lump sum. Pension plans pay out benefits out as a monthly pension for the rest of the insured person's life. Up to one-third of total benefits can be commuted into a lump-sum payment if the plan is contributory ( $25 \%$ if non-contributory). The Board of Trustees is required to give the scheme member the opportunity to choose their annuity provider and preferred annuity. Plan rules may provide for different benefit formulas for different categories of workers under certain circumstances. Both lump sum payments and annuities enjoy more generous tax treatment, as long as the member retires on disability or age grounds, or has been a member of a retirement benefits scheme for at least 10 years. Pensions are tax-free for pensioners receiving up to KShs26,000 and have no other sources of income, or KShs 15,000 if they have other sources of income. With effect from June 2007, pensions for individuals above the age of 65 are not taxable. For non-tax-registered retirement benefits schemes, contributions and investment income are taxable at normal tax rates. However, no further tax is exercised on the savings after the member retires.

Retirement benefits schemes are run by trustees. Half of the trustees are nominated by the members, and half are nominated by the employer. All trustees are required to engage the services of an assets manager for the management of their assets. A reform in 2005 abolished the possibility for workers to withdraw all their assets before reaching the normal retirement age. Since then, workers can only withdraw their employer's portion of contributions if they have been members of the scheme for less than one year, and if the vesting rules allow them to make such a withdrawal. They can withdraw their own contributions before reaching the age of 55 if they are withdrawing from a retirement benefits scheme. With effect from January 2008, they will also be allowed to assign their savings as mortgage security.

In 2007, there were around 1357 active occupational pension schemes, of which approximately $10 \%$ were DB schemes. The majority of schemes are pension schemes as opposed to provident funds. As of 2006, pension fund assets amounted to around 250bn KES (c $\$ 3.5 \mathrm{bn}$ ). Investment restrictions include up to $70 \%$ in domestic and regional shares, $15 \%$ offshore and $30 \%$ in real estate.

In terms of personal pension arrangements, 14 individual, DC-type pension schemes exist, which cover less than $1 \%$ of the population. They are mostly offered by insurance companies and are available to anyone. They are attractive to those workers whose employers do not offer a pension plan and to the selfemployed. In May 2007, the Zimele Personal Pension Plan, a voluntary retirement savings arrangement for all public- and private-sector workers, was introduced. It will be managed by the private firm Zimele Asset Management Company. The plan operates on the basis of pooled funds. Contributions and investment income are exempt from tax. Amana Personal Pension Plan is the only other individual retirement benefits scheme that is similarly structured to the Zimele Personal Pension Plan.

The pension system in Kenya has been supervised by the independent Retirement Benefits Authority (RBA) since 2000, which oversees the 1997 Retirement Benefits Act, which brought regulation, protection and structure to the pension industry. The RBA continues work to develop the industry and train trustees.

However, challenges still remain for the RBA, including bringing some funds in line with the law and to a fully funded level. Post-retirement poverty, low coverage, low contributions rates and the HIV/AIDS 
epidemic (which had reduced the life expectancy of Kenyans to below the normal retirement age) present challenges for the Kenyan pension system. The introduction of a "zero" pillar has been proposed, providing universal minimum pension to the population over 65. The Civil Servants Pension Scheme, noncontributory, may be reformed to introduce employee contributions and a revision of the retirement age from 55 to 60 . There have also been proposals to introduce a mandatory element into the voluntary occupational and individual schemes and to create a "fourth" pillar in the form of tax incentives for family support and the purchase of a home.

\section{Lesotho}

The social pension in Lesotho was introduced in 2004. Everyone over the age of 70, except those people already receiving a government pension, receives M150 (US\$22) each month. Photo identification is needed to register for the pension, which is paid at post offices throughout the country, with around $3.6 \%$ of the population eligible (in 2006 about 72,000 people, $96 \%$ of those eligible, were receiving the pension, and more than half of these were women). The scheme is administered by the Ministry of Finance and Development Planning and financed out of the state budget (amounting to $2.4 \%$ of the national budget, or $1.43 \%$ of GDP).

\section{Malawi}

In the absence of national policy, pension coverage in Malawi is currently low. With no formal social security scheme, there is little security for retirees. Currently there are around 600 private pension funds in the country, offering DB and DC pensions, and an Umbrella fund. Three Administrators operate, but there is no active supervision or regulation of the market.

In 2005 the Government and the Reserve Bank of Malawi (RBM) started an initiative - within the context of broader financial sector reforms - to develop a regulatory framework for the supervision of pension funds. The reforms will include provisions for the registration of all funds and licensing of other market players (trustees, administrators, fund managers, custodians) based on fit and proper criteria. Funds should be structured as trusts, with assets held by a custodian. Controls for contributions will be put in place, and fund rules and benefit protection methods checked. Investments in high risk areas will be restricted and the information provided to members controlled. Tax treatment will be handled a later stage of reform.

\section{Mauritius}

The pension system in Mauritius consists of a universal, non-contributory Basic Retirement Pension, two mandatory, income-related pension schemes for the private sector (National Pension Fund and National Savings Fund) - which are administered by the public sector - and a number of voluntary schemes providing supplementary pension income.

The Basic Retirement Income is a universal, non-contributory pension funded by government taxation. It provides a minimum income guarantee for the elderly, covering all persons over 60 resident in Mauritius. The monthly retirement income provided is Rs1500 (1999/2000). Benefits are index linked, with a 5-year adjustment to prices. Payments increase for the very old (85s, 90s, 100s). Around 150,000 beneficiaries are covered (around $3 / 4$ receiving old age benefits, the remainder widows, invalids and orphan benefits). Public sector employees (civil servants and parastatal employees) are covered by a separate scheme, which has been criticized as being overly generous vs. the private sector schemes, providing $66.7 \%$ of final salary for 33.3 years of employment 
In terms of occupational pensions, membership of the National Pension Fund Scheme (NPF) and National Savings Fund (NSF) is mandatory for all private sector employees with one month lifetime employment.

The NPF is a partially funded scheme requiring $9 \%$ contribution (13.5\% for the sugar sector), whilst the NSF is a fully funded scheme requiring $2.5 \%$ contributions.

Benefits are paid from age 60 and are points based. The government also guarantees a minimum pension obligation (Rs 218 2000) to those who have made a one-time/ one month contribution to the fund.

$\mathrm{NPF}$ - aims at $33.3 \%$ replacement rate of average lifetime earnings for 40 years of employment - but is said to not be meeting these expectations and is likely to deliver only a $15 \%$ replacement rate. The average payout from the fund in 2000 was Rs 522 per month (218 minimum pension +423 NPF average). The NSF is a DC scheme paying lump sum benefits only. The NPF and NSF are administered by the public sector, with assets amounting to around 19\% of GDP, $17 \%$ in the NPF and 2\% in the NSF (World Bank 2004). Around 220,000 employees are covered by the schemes (c15,000 employers) with around 36,000 beneficiaries receiving payments.

Around 1000 voluntary, occupational pension schemes are also in operation. Most of the estimated 25,000 members are highly paid workers (coverage estimated at around 10\%), either in schemes insured and/ or administered by insurance companies of self-administered superannuation funds. Contributions to the schemes are made by employers only - usually at a rate between $12-19 \%$ of earnings. The schemes are predominantly DB based, with benefits paid out as pensions or lump sum (insured funds only). Of the 25,000 members 13,500 are in insured funds and 11,500 in registered superannuation funds. Funds are said to be low cost (possibly as sponsoring companies absorb some of the costs of larger funds).

Mauritius is facing a demographic transition much sooner in its development cycle than other upper income and high income countries have experienced. The share of i t s over-60 population i s expected to more than triple in the next 50 years. The unfunded universal scheme and the civil service scheme are therefore becoming an unsustainable financial burden on the government. Declining benefits from the contributory scheme and a lack of a regulatory environment for private savings (discouraging private savings through the formal financial system) are jeopardizing living standards in retirement. In addition public sector management of the private contributory schemes does not deliver maximum returns, whilst private sector savings are unlikely to grow given the lack of regulation and development of domestic financial markets.

The government therefore recognizes the need for reform of the pension system, and has held a widespread debate on the topic in recent years, including a comprehensive World Bank (2004) review of the system issued in 2004 which recommended the follow:

- reduce fiscal risk by modernizing the Basic Retirement Pension;

- render the system more equitable (through continued, and possibly higher transfers to the poor, maximize retums for contributors);

- $\quad$ render the system more efficient (by diversifying risk and enabling resource allocation);

- improve transparency in management through introduction o f regulation and a supervisory agency for pensions;

- introduce flexibility in the system, especially regarding the retirement age. 


\section{Namibia}

The Namibian pension system consists of a universal pension scheme the (National Pension Scheme), and voluntary contributory private pensions.

The National Pension Scheme (NPS), known as the Universal Pension Scheme, is a social pension, which provides a flat-rate benefit, is non-contributory and non-taxable and payable regardless of other income. As of $2005, \mathrm{~N} \$ 300$ in monthly benefits were provided to around 100,000 pensioners. The pension is payable to all resident Namibian citizens (who are not outside the country for more than 6 months) above the age of 60 . The pension is funded from government taxation. Most pensioners $(85 \%)$ receive their money at a designated cash pay point, with the rest via a post office or bank. The overhead costs of the NPS are said to be relatively high.

The government also launched the Namibia Agricultural Retirement fund to cover agriculture related workers. This DC scheme is funded with $10 \%$ contributions, evenly split between employees and employers (who also pay an additional $1 \%$ for administrative fees).

The Government Institutions Pension Fund (GPIF) covers civil servants. This is a fully funded, DB scheme and is the largest pension fund in the country with assets of $\mathrm{N} \$ 15.1 \mathrm{bn}$ (2004) - or $73 \%$ of total pension assets in the country.

Around 15,000 workers are covered by taxable, contributory schemes (frequently on generous terms). Around 500 private pension funds currently operate in the country, with total pension assets in 2004 amounting to $\mathrm{N} \$ 25 \mathrm{bn}$, or $68 \%$ of GDP. Most funds are small and are administered by external fund administrators that provide basic recordkeeping as well as more specialized legal and actuarial services (the largest pension fund administrator has a 60 percent market share). There are also a small number of pension funds that are administered and insured by life insurance companies. These funds have total assets of $\mathrm{N} \$ 2.4$ billion that are included with insurance company assets in published statistics. The remaining $\mathrm{N} \$ 5.6$ billion was held by various smaller funds, the bulk of which are based on defined contribution plans. The average size of private pension funds is less than $\mathrm{N} \$ 12$ million, implying that pension fund operations may be suffering from small scale diseconomies. However, several plans belong to umbrella funds in an attempt to lower operating costs and enhance investment performance.

Pension funds invest heavily abroad give a lack of domestic investment opportunities and due to strong links with South African financial institutions. While equity allocation appears high in comparison to other emerging market countries, it is similar to allocations in developed countries. Several factors have contributed to this outcome ${ }^{10}$ :

- data shows that about 60-70 percent of assets are invested in equities and unit trusts,and these have so far performed well. Holdings of government bills and bonds havefluctuated between 1020 percent;

- under Regulation 28, pension funds are required to invest a minimum of 35 percent inlocal assets but its flexible implementation to include the dual listed equities on the Namibia Stock Exchange (NSX) as local assets has allowed continued diversification and good performance.

Currently only around $6 \%$ of Namibia's population is over 60 . This is expected to rise to $21 \%$ in the coming decades (with the old age dependency ratio likewise rising from $11 \%$ to $36 \%$ on World Bank

\footnotetext{
${ }^{10}$ IMF Namibia Financial Stability Report http://www.imf.org/external/pubs/ft/scr/2007/cr0783.pdf
} 
estimates). The government recognises that existing pension arrangements are not well suited to an ageing population. Reforms to make the system more redistributive are therefore being considered.

A National Pensions scheme has been proposed. This is a contributory, PAYG scheme, under which the contributor could retire with 15 years of contributions after the age of 60 . The plan would be redistributive by replacing a larger \% of lower income workers' wages. The government is in the process of designing a simple means test (income and asset based).

\section{Niger}

Niger has two mandatory pension systems that provide income protection to a very small group of the population (only 3 percent of the labor force), however pension spending has been increasing exponentially during the last few years. The two different pension schemes provide pensions to workers of the public and private sector. "Caisse Nationale de Securite Sociale" (CNSS) manages pensions for the private sector, and "Fonds Nationale de Retraite" (FNR) those of the public sector. CNSS_was created in 1965, but some rules have been modified since then. On the other hand, FNR was created earlier, in 1961, and since then there have not been any significant changes of its rules and regulations.

The institution of CNSS manages three social security branches: family allowances, work injuries, and pensions (old-age, invalidity, and survivors). It also manages a "social and health fund". On the other hand, FNR pays only old-age pensions, invalidity, survivorship, plus family allowances. FNR is not an autonomous body, but completely linked to Treasury.

The contribution rate in CNSS is 17 percent (15.4 from employer, and 1.6 from employee) of individual's covered earnings, however only 4 percent is for the pension branch. The contribution rate for family allowances is 11 percent and 2 percent is for work injury. FNR is also supposed to collect contributions from both employees (6 percent of payroll), and the government-employer (14 percent), however it does not receive the mandatory employer's contribution on a regular basis.

Despite low coverage, as earlier mentioned, pension expenditures have been growing and the overall deficit of the pension system in Niger (CNSS and FNR) is already around 0.3 percent of GDP, or 37 percent of the government primary deficit. In the CNSS expenditures have been growing by around 10 percent per year and are now at FCFA 4.7 billion (almost 0.3 percent of GDP). With revenues of only FCFA 2 billion, the CNSS is displaying a deficit of around 0.15 percent of GDP. This deficit of the pension branch is currently financed by the surplus of the family allowance one. In the FNR, the expenditures have increased at a faster pace (around 14 percent per year) and in 2006 these reached FCFA 9.8 billion ( 0.5 percent of GDP). The deficit of the system is estimated at 0.19 of GDP. So the overall deficit of the mandatory pension system is close to 0.3 percent of GDP or almost 40 percent of the aggregated primary deficit of the government which accounts for almost 1 percent of GDP.

Benefits are quite modest in the case of private sector workers and call for a review of the mandate of the social security system as a whole and a reallocation of payroll taxes. The replacement rates for a full career worker (40 years of contribution) retiring at age 60 are about 55 percent for the CNSS. Although this replacement rate can be considered appropriate, the reality, however, is that few workers in the private sector are full-career. Many contribute to the pension system for only half of their active life. The effective replacement rates can therefore be below 40 percent and this raises concerns about the adequacy of the current system to prevent poverty during old-age. Like in the case of wages, higher real pensions can only come from higher labor productivity. Nonetheless, the value of pensions relative to wages could increase by allocating a larger portion of the total social security pay-roll tax to finance pensions. This would require reviewing the level of other benefits within the CNSS - particularly family allowances which arguably should not be part of a social risk management system. 
On the contrary, the pension plan for civil servants is quite generous and could contribute to a regressive distribution of public expenditures. The replacement rate for a full-career civil servant retiring at age 60 is 80 percent. Because civil servants also have longer careers replacement rates are also high. These pensions today are financed essentially out of the general budget. Thus, other things being equal, higher pension for civil servants imply a lower budget to allocate to finance the production of public goods, social investment in education, health and infrastructure, as well as transfers to the poor. Thus, in a country like Niger the opportunity costs of higher pensions for civil servants is likely to be much higher than in middle and high income countries.

\section{Nigeria}

The Contributory Pension Scheme (CPS), which was established by the Pension Reform Act 2004, is contributory, fully funded, DC, privately managed and based on individual accounts. Existing private sector pension schemes are allowed to continue provided there is evidence to show that the pension scheme is fully funded at all times, any shortfall will be made up within 90 days, pension funds assets are segregated from the assets of the employer/company, the pension funds assets are held by a licensed Custodian and the scheme is specifically approved by the National Pension Commission.

Membership in the CPS is compulsory for all public sector employers (except diplomats) and for those private sector employers with 5 or more employees. Retirement Saving Accounts are set up for all covered employees under the CPS. Some groups of employees are exempted from the contributory pension scheme, for example those who, at the coming into force of the Pension Reform Act 2004 are covered by a different pension scheme, which existed before the commencement of the Pension Reform Act 2004 and who have 3 years or less to retire. Public services employees and private sector employees pay a minimum of $7.5 \%$ of their gross monthly earnings. Employers also pay a minimum contribution of $7.5 \%$ and may pay the full $15 \%$ themselves. Military personnel pay a minimum of $2.5 \%$ of their gross monthly earnings and their employers pay $12.5 \%$. The gross monthly earnings comprise basic salary, housing allowances and transportation allowances. Voluntary contributions are allowed. Contributions may be revised upwards by agreement between the employer and the employee. The National Pension Commission must be notified of this revision.

Upon retirement the member has a choice as to how to receive his retirement benefits:

- $\quad$ programmed monthly or quarterly withdrawals, based on life expectancy;

- $\quad$ annuity for life purchased form a life insurance company (with monthly or quarterly payments);

- a lump sum, provided that the amount left after that lump sum withdrawal is sufficient to permit an annuity or programmed withdrawals of at least 50 per cent of the employee's annual preretirement salary.

If the employee retires before the age of 50, a maximum of $25 \%$ of retirement savings can be withdrawn as a lump sum (six months after retirement and the individual cannot re-enter the workforce). All retirement savings account holders who have contributed for 20 years are guaranteed a minimum pension as specified by the Government on the recommendation from the Pension Commission. Additional or voluntary lump sum contributions into the RSA can be withdrawn before retirement or attainment of the age of 50 years.

Contributions to the new pension scheme are tax free. Investment income is taxed. Benefits are exempted from tax. Early withdrawals (withdrawn from voluntary additional contributions) are taxed. 
Pension funds can only be managed by pension fund administrators who have obtained a licence from the National Pension Commission. The employee is free to choose an administrator. Custodians hold the employees assets and execute transactions for the employee. The Pension Reform Act provides that administrators may only charge clearly defined and reasonable fees. Pension funds and assets can be invested in:

- bonds, bills and other securities issued or guaranteed by the Federal Government and the Central Bank of Nigeria;

- bonds, debentures, redeemable preference shares and other debt instruments issued by stocklisted corporations;

- ordinary shares of public limited companies listed on the stock exchanges with good track records having declared and paid dividends in the preceding five years;

- $\quad$ bank deposits and bank securities;

- investment certificates of closed-end investment fund or hybrid investment funds listed on a Stock exchange with a good track record of earning;

- units sold by open-end investment funds or specialist open-end investment funds listed on the stock exchange recognised by the Pension Commission;

- bonds and other debt securities issued by listed companies;

- real estate;

- $\quad$ such other instruments as the Commission may prescribe.

Nigeria was the first country in sub-Saharan Africa to introduce a pension system based on 'Chilean style', individual, funded accounts. The questions which arise from this experiment are whether the infrastructure was and is in place to support the operation of such a system and - even if so - whether it is appropriate for a country such as Nigeria. There has been some criticism that the country was a different level of development to Chile when the reforms were introduced (in terms of economic, social and pension system development) and that there was a lack of governance, records, financial institutional capacity and market development. Moreover, as $90 \%$ individuals work in the informal sector, the new system is unable to meet the fundamental goal of providing most Nigerians with access to formal social security programmes. Some have therefore argued that Nigeria still needs a basic social pension - which the Chileans are introducing through reforms to their own system.

\section{Senegal}

Two pension schemes currently operate in Senegal - the Fonds national de Retratie (FNR) for private sector workers and the Institutoin de Prévoyance Retraite du Sénégal (IPRES) for civil servants. These are partially funded systems (most of the reserves are for the IPRES scheme).

Senegal is adopting a gradual approach towards building a sustainable retirement system. A extensive consultation process and debate on pension reform is underway in the country, with the Ministries of Finance and Labour consulting with social security institutions, unions and other stakeholders. Reforms to reign in the cost of the FNR scheme were initiated in 2002 (including change of the benefit formula, rise of 
the retirement age, and indexation of benefits). Further steps could include integrating the two existing systems, and the introduce a fully funded, mandatory DC based pension system is also under consideration.

\section{South Africa}

Although the main source of income for over $75 \%$ of individuals over the retirement age in South Africa is a means tested, social grant (the SOAG), the country does also have a well developed occupational pension and private retirement savings system, albeit with a limited coverage of the working population.The South African government is currently undertaking extensive reforms of the system to improve both the depth and coverage of pension benefits.

The public pension provides a non-contributory, means- tested old age pension. The system is financed by general revenues. The pension is payable to women at 60 and men at 65 who are resident citizens of South Africa. Benefits amount to up to 940 rand a month for a single pensioner. Married couples may receive double the amount. The pension is reduced to $25 \%$ of the full amount for pensioners who are resident for more than 3 months in a private care institution. A means test is currently applied, which lowers the benefit by 50 cents for every R1 of other income, to a level of zero when other income exceeds $\mathrm{R} 1,880$ per month. This is the main source of income for $75 \%$ of retirees, most of whom receive the full amount. Special grants are paid to war veterans (up to R838) and pensioners who need full-time attendance of another person as the result of a mental or physical condition (R180). The benefit level is informally linked to wages (following inflation erosion in the 1990s), and relative to average formal sector wages, provides a reasonable replacement rate to lower income workers who reach retirement age as well as acting an important source of poverty relief for those who are unemployed through most of their working lives. Originally, in the Apartheid era it was introduced to cover small numbers of low-income, white workers, but was gradually extended to all South Africans, with parity payments for all ethnic groups achieved in the 1990s.

The private and funded pension system consists of an occupational and personal tier. There are also occupational pension funds for civil servants, as well as for workers of state companies. Many middle to upper income workers belong to an occupational fund as well as make supplementary retirement prevision through the use of individual retirement funds (called "retirement annuities") which are similar in character to $401(\mathrm{k})$ plans in the United States. Occupational pension provision is provided through pension funds (which must pay out a least $2 / 3$ in annuities with employee contributions tax exempt), or provident funds (which are permitted to pay $100 \%$ of the member' $s$ benefit in the form of a lump-sum).

In terms of voluntary, occupational pensions, employers decide whether to set up a fund, what type and categories of employees eligible, after which all workers in a category must join. For this reason, the system though legally voluntary can be thought of as quasi-mandatory. In some instances, employers are free to decide contribution levels and there are no minimum or maximum contribution limits, unless so provided for in the rules of the fund. In other cases, the rates of contribution are an outcome of negotiation between labour representatives and employers (this is the case in many so called "bargaining council" and industry funds which effectively act as multi-employer funds). Additional voluntary contributions are allowed, if the rules of the fund concerned permit. The tax deductible contribution for employees is equal to the greater of 7,5\% of remuneration or R1,7501. The tax deductible contribution for employers is a minimum of $10 \%$ of approved remuneration. In practice, the South African Revenue Services (SARS) allows up to $20 \%$ tax deductible contributions towards pension and provident funds. Investment returns are not taxed and benefits are taxed as earned income, with a certain tax-free lump sum permitted.

Pension schemes can be pure defined benefit (DB) or defined contribution (DC), or some hybrid of the two. Pension funds must pay out a least $2 / 3$ in annuities (maximum $1 / 3$ as a lump sum); provident funds may pay out $100 \%$ lump sums. Generally the employer is free to decide the benefit structure and the 
age at which they become available when setting up an occupational scheme. Market The majority of employees in the formally employed private sector in South Africa belong to defined contribution (DC) schemes, while public sector funds are still largely defined benefit (DB) arrangements. The South African environment has also seen considerable growth of multi-employer or "umbrella" funds, which are DC in nature. Most of the large trade unions have established national defined contribution funds and have negotiated an option for their members to belong to such funds, as opposed to membership of an employersponsored fund. In effect therefore, such funds are multi-employer funds, but along industry lines. Umbrella funds, covering multiple employers, are also allowed and have increased in number over time.

Viewing the pensions market as a whole, in 2004 there were around 13,700 funds, - over 10,000 a underwritten by insurance companies - with almost $9 \mathrm{~m}$ members and R1,1 trillion assets. Some double counting exists in terms of the number of members, as some individuals are members of more than one fund (for example, may belong to a retirement annuity fund as well as an occupational fund established by their employer). Many funds also offer death and disability benefits.

Additional tax-incentivised saving for retirement occurs through voluntary savings vehicles, mainly in the form of Retirement Annuity ("RA") fund policies, primarily offered by the insurance sector. There are some 2,5 million members of RA funds, across a wide range of income levels, making substantial contributions to supplement those made to occupational pension funds. These are implemented through retirement annuity funds. Estimates by the National Treasury places coverage at approximately $60 \%$ of workers in the formal sector. However, no statistics exist for pension provisioning in the informal sector.

In the case of retirement annuitites, benefits become available from age 55 onwards. They can be paid out as annuity or as a combination of a lump sum (1/3 of assets) and annuity. Contributions are taxdeductible up to $15 \%$ of taxable income. Investment yields are subject to beneficial tax rules, for example exempt from capital gains tax. A lump sum payment is tax free up to R300,000 . Beyond this point, larger lump-sums are taxed up to 36\%. Market In 2005, R23 billion contributions were made to underwritten funds. This consists of retirement annuities and insurance policies which are purchased by an employer on behalf of their employee.

Reform proposals include the introduction of a contributory social security pillar as well as (where applicable to persons) supplementary mandatory contributions to the private retirement funding arrangements in order to improve the coverage rate and tackle 'leakage' problems (early withdrawals leading to substantial sums of money being taken out of the funded pension system). The primary objective of this reform is to ensure a basic level of income during retirement for all South Africans. Currently, almost $80 \%$ of funds have less than 100 members, which has tended to raise concerns about the availability of sufficiently trained trustees to govern these funds and the cost-efficiency of such arrangements for the members within these funds. The tax treatment of occupational pension fund and retirement annuity fund contributions will be aligned, so as to remove any potential discrimination against the self-employed, as well as aid portability of pension entitlements across the various pillars of provision.

\section{Uganda}

Uganda operates a provident fund system, covering permanent employees aged 16-54 in firms with more than 5 workers. Voluntary participation is also possible, with a separately run (generous) scheme for government employees (the Public Sector Pension Fund - PSPF). The scheme is funded with 5\% contributions from employees and 10\% from employers (no maximum or minimum earning levels apply for contribution purposes). Benefits are paid from age 55 in the form of a lump sum equal to total contributions plus accrued interest (which is determined based on the rate of return of the National Social Security Fund investments). In recent years the government of Uganda has expressed strong interest in reforming the provident and public sector pension funds. 


\section{Zambia}

Reforms since the 1990s have transformed Zambia's provident fund system into a pension system consisting of a mandatory, privately managed, partially funded, defined benefit schemes. Voluntary occupational pension's schemes also exist. A pension regulator, the Pensions and Insurance Authority, was established in 2000.

Zambia's National Provident Fund (ZNPF) was restructured in the 1990s and converted to a basic, compulsory, social insurance scheme, administered by the National Pension Scheme Authority (NAPSA).

Members of the NAPSA are old members of the ZNPF and new employees, including central and local government civil servants who started work from 2000. All employed persons (including agricultural workers, domestic servants in urban areas etc.) are covered. Voluntary coverage is for the self-employed and some categories of informal-sector workers who were previously covered for at least 60 months (NB $88 \%$ of workers in Zambia are part of the informal sector and only 3\% are fully part of the formal sector).

Workers younger than 16 or over 55, or earning less than K15,000 a month, and armed forces personnel are excluded.

The scheme is funded by $5 \%$ of covered earnings ( $10 \%$ for voluntary contributions) contributed by the employee and 5\% from the employer. The maximum monthly earnings for contribution purposes are equal to $4 \mathrm{x}$ national average monthly earnings.

Pensions are paid to those over 55 with at least 180 contributions who have retired from regular employment. A reduced early pension is paid from age 50 with at least 180 contributions is the resulting reduced pension is at least equal to the minimum pension. Pension payments are adjusted annually in line with national average earnings. The monthly pension is equal to the insured's average adjusted monthly earnings $\mathrm{x}$ no. of months of contribution. The minimum monthly pension is equal to $20 \%$ of national earnings and the maximum $40 \%$ of the insured's average adjusted monthly earnings. Benefits are portable across employment opportunities. An old-age settlement is paid if the insured does not qualify for the oldage pension, which is a lump sum equal to the total adjusted contributions from the insured person and the employer + accrued interest. The NAPSA is not as yet fully funded as the government has been defaulting on its mandatory contributions.

The pension scheme for teachers and armed forces was merged with the Civil Service Pension Fund in 1996 (Public Service Pension Fund - PSPF). A Local Authorities Superannuation Fund (LASF) also still operates. Monthly pensions are low for those in the PSPF and LASF due to the size of the lump sum which can be taken upon retirement. Parametric reforms for these schemes have been planned but as yet not implemented (due to Constitutional protection for some civil servant benefits), and the schemes remain in deficit.

The scope of coverage of the social security schemes is limited, given that (according to ILO estimates $^{11}$ ) $88 \%$ of all employed workers are in the informal economy and only $3 \%$ in a fully formal environment.

Voluntary, occupational pension schemes may be set up by employers singly or as a group (collective bargaining is usually part of establishing a plan). Plans must be authorized by the Registrar or Pensions and Insurance (RPI) and are organised on a trust basis (with a board made up of equal numbers of employer

\footnotetext{
${ }^{11}$ Zambia Social Protection Expenditure and Performance Review and Social Budget Social Security Department
} ILO June 2008 ILO/DFID/Zambia/R.22bis 
and employee representatives). Employers are required to contribute, usually at double the rate of employee contributions (between 10-20\% of salary). Employers sponsoring a DB plan sometimes do not contribute a fixed rate but pay what is necessary, in addition to employee contributions, to ensure that liabilities are properly funded. Plans may be contributory or non-contributory for employees, as specified in the plan rules. Employees usually pay one-third of the total contributions. In practice most plans are contributory at a rate of 5 (most usual)-10\%. Tax rules require a minimum retirement age of 55 (45 for some types of work if approved by the relevant authorities). Plans may be DB or DC (most large plans being the former, smaller plans the latter). Many plans are shifting from DB to DC arrangements. Benefits are usually paid as pension, with the greater of ZMK 5milion or $50 \%$ of the cash value of the pension rights payable as a lump sum. Employee contributions are tax deductible up to ZMK 60,000 month, with employer contributions deductible up to $20 \%$ of payroll. Investment income is taxed at the withholding tax rate on all government securities of 15\% (dividend income tax exempt) and benefits are tax exempt.

Trustees must contract out asset management to an asset manager (i.e. an administration company, bank, insurance company or registered financial services company). Plan assets may be invested in bonds, treasury bills, equity or cash. Up to $30 \%$ of assets may be invested abroad. Fees are not regulated but determined by the market.

Alternative pillars to provide greater diversity in pension saving options has been proposed, but have not been able to proceed without further reform of the NAPSA system. The main problems identified in the area of private pension funds are a lack of legislation,_regulation and supervision of occupational pension plans, a lack of secure and profitable investment_opportunities which explains why the portfolios of all private pension funds consist only of Treasury Bills_and real estate, and a lack of qualified management personnel.

\section{REFERENCES}

Barrientos, A., (2005), 'Non-contributory pensions and poverty reduction in Brazil and South Africa', IDPM, University of Manchester

Bogomolva, T., Impavido, G., Pallares-Miralles, M., (2007), 'An Assessment Of Reform Options For The Public Service Pension Fund In Uganda’ World Bank Policy Research Working Paper 4091

http://www-

wds.worldbank.org/external/default/WDSContentServer/IW3P/IB/2007/02/28/000016406_2007022 8142040/Rendered/PDF/wps4091.pdf

Casey, B.H., Dostal, J.M., (2007), 'Pension Reform in Nigeria: how not to "learn from others", Global Social Policy (2008) vol.8, no.2

http://www.psa.ac.uk/2007/pps/Dostal.pdf

Catalan, M., Impavido, G. and Musalem, A. B. (2000), Contractual Savings or Stock Market Development: Which Leads?, Pension Primer Paper, The World Bank, Washington, D.C. 
Corbo, V. and Schmidt-Hebel, K. (2003), "Efectos Macroeconómicos de la Reforma de Pensions en Chile", mimeo, September 2003.

Davis, E. P. (2002), "Institutional Investors, Corporate Governance, and the Performance of the Corporate Sector”, Economic Systems, 26, pp. 203-229.

Davis, E. P. and Hu, Y. (2004), "Is There a Link Between Pension Fund Assets and Economic Growth? A Cross-Country Study", mimeo, Brunel University and NIESR.

Dei, H., (2001), 'Public Pension Fund Management in Ghana', World Bank http://www1.worldbank.org/finance/assets/images/Henry_Dei_Paper___Ghana.pdf

Genesis Analytics (forthcoming), 'Developing a Broad-based Employee Pension Scheme for Botswana', commissioned by FinMark Trust

Help Age International, (2002), Why Social Pensions are Needed Now http://www.helpage.org/Researchandpolicy/PensionWatch

Help Age International (2006a), 'A transformative agenda for the $21^{\text {st }}$ century: Examining the case for basic social protection in Africa', Background briefing for the Intergovernmental regional workshop, Livingstone, Zambia

http://www.socialcashtransferszambia.org/mediapool/28/282961/data/Zambiabackgroundnotefinalversionwithcover_1_.pdf

Help Age International, (2006b), 'Why Social Pensions are needed now', Help Age International Briefing on Social Pensions' http://www.globalaging.org/pension/world/2007/needed.pdf

Holzman, R., Hinz, R., 'Old Age Income Support in the $21^{\text {st }}$ Century', World Bank 2001

http://siteresources.worldbank.org/INTPENSIONS/Resources/Old_Age_Income_Support_FM.pdf

Impavido, G., Musalem, A. R. and Tressel, T. (2003), The Impact of Contractual Savings Institutions on Securities Markets, mimeo, The World Bank, January 2003.

International Organisation of Pension Supervisors, Country Case Studies

http://www.iopsweb.org/pages/0,3417,en_35030657_38606785_1_1_1_1_1,00.html

International Organisation of Pension Supervisors, IOPS Principles of Private Pension Supervision

http://www.iopsweb.org/dataoecd/59/7/40329249.pdf

Kakwani, N., Subbarao, K., 'Aging and Poverty in Africa and the Role of Social Pensions', World Bank Social Protection Discussion Paper Series, 2005

http://siteresources.worldbank.org/SOCIALPROTECTION/Resources/0521.pdf

Lefort, F. and Walker, E. (2002), “Pension Reform and Capital Markets: Are There Any (Hard) Links?", Social Protection Discussion Paper Series, The World Bank, February 2002.

McKinnon, R., Sigg, R., 'The Role and Nature of Non-Contributory Social Security in the Design of Social 
Protection Strategies for Older People in DCs', ISSA Geneva

http://www.gov.mu/portal/sites/ncb/mac/nlibrary/efiles/secu3.pdf

Moller, V. and Ferreira, M. (2003), 'NCPPS South Africa Survey Report' Cape Town http://idpm.man.ac.uk/ncpps/report.htm See http://www.helpage.org/Researchandpolicy/PensionWatch/Impact

OECD Principles for Private Sector Participation in Infrastructure www.oecd.org/daf/investment/ppp

OECD Recommendation on Core Priciples of Occupational Pension Regulation http://www.oecd.org/dataoecd/14/46/33619987.pdf

Palacios, R., Pallares-Miralles, M., "International Patterns of Pension Provision”, Pension Reform Primer working papers series 2000, www.worldbank.org/pensions.

Palacios, R., Sluchynsky, O., (2006), 'Social Pensions Part I: Their Role in the Overall Pension System', Social Protection Discussion Paper No. 0601 http://siteresources.worldbank.org/SOCIALPROTECTION/Resources/SP-Discussionpapers/Pensions-DP/0601.pdf

Queisser, M., Bailey, C., Woodall, J., (1997) 'Reforming Pensions in Zambia: An Analysis of Existing Schemes and Options for Reform', The World Bank Financial Sector Development Department

http://www-

wds.worldbank.org/external/default/WDSContentServer/IW3P/IB/1999/08/15/000009265_3970625 093958/Rendered/PDF/multi_page.pdf

Save the Children, Help Age International and Institute for Development Studies, (2005), 'Making Cash Count; Lessons from cash transfer schemes in east and southern Africa for supporting the most vulnerable children and households'

United Nations, (2007), 'World Economic and Social Survey 2007: Development in an Ageing World' (E/2007/50/REV.1 st/esa/314) http://www.un.org/esa/policy/wess/wess2007files/wess2007.pdf

van Dullemen, C., (2007) 'Pensions in Developing Countries: A quest for modern format for intergenerational solidarity', United Nations http://www.un.org/esa/socdev/unyin/documents/egm_unhq_oct07_vandullemen.pdf

Vittas, D., (2003), 'The Role of Occupational Pension Funds in Mauritius', The World BankFinancial Sector Operations and Policy Department, Working Paper 3033

http://wwwwds.worldbank.org/external/default/WDSContentServer/IW3P/IB/2003/05/23/000094946_0 3051404103339/Rendered/PDF/multi0page.pdf

Willmore, L., (2003), 'Universal Pensions in Mauritius- A lesson for the rest of us', World Bank, United Nations, DESA Discussion Paper No. 32

http://unpan1.un.org/intradoc/groups/public/documents/UN/UNPAN009128.pdf 
World Bank (2004), 'Mauritius - Modernizing an Advanced Pension System', World Bank, Poverty

Reduction and Economic Management I, Southern Africa, African Region, Report No. 29588-MU

http://www-

wds.worldbank.org/external/default/WDSContentServer/WDSP/IB/2004/07/22/000012009_200407 22102019/Rendered/PDF/295880MU.pdf

World Economic Forum, (2008), 'Financing Demographic Shifts: The Future of Pensions and Healthcare in a Rapidly Ageing World', World Scenario Series, January 2008

http://www.weforum.org/pdf/scenarios/Report.pdf

\begin{abstract}
APPENDIX 1
ILO definitions of types of mandatory systems for retirement income categorized in Table 1:

Flat-rate pension: A pension of uniform amount or one based on years of service or residence but independent of earnings. It is financed by payroll tax contributions from employees, employers, or both.

Earnings-related pension: A pension based on earnings. It is financed by payroll tax contributions from employees, employers or both.

Means-tested pension: A pension paid to eligible persons whose own or family income, assets, or both fall below designated levels. It is generally financed through government contributions, with no contributions from employers or employees.

Flat-rate universal pension: A pension of uniform amount normally based on residence but independent of earnings. It is generally financed through government contributions, with no contributions from employers or employees.

Provident funds: Employees and employer contributions are set aside for each employee in publicly managed special funds. Benefits are generally paid as a lump sum with accrued interest.

Occupational retirement schemes: Employees and, in some cases, employers must contribute a certain percentage of earnings to an individual account managed by a public or private fund manager chosen by the employee. The accumulated capital in the individual account is used to purchase an annuity, make programmed withdrawals, or a combination of the two and may be paid as a lump sum.
\end{abstract}

